\title{
Third molars and premolars extraction in conventional orthodontics and in treatments based on maxillary bone remodeling with temporary anchorage: indications and care
}

\author{
Alberto Consolaro ${ }^{1}$
}

DOI: http://dx.doi.org/10.1590/2177-6709.22.1.023-031.oin

\begin{abstract}
A bone is an anatomic structure in constant remodeling, with different, mutant and wonderfully inconstant designs. With every new and immediate functional demand, there are changes in cortical thickness, trabecular bone density and also in direction and size of trabeculae. Bones' non-stopping search is for adjusting to the functions induced by forces and movements required by a certain life style. Conventional orthodontic planning or with temporary anchorage based on bone remodeling takes into consideration the spaces that are - or may be - occupied by the teeth, in the formation of a functional and esthetic dental arch for the patient. In case it is necessary to extract a tooth and the options are the third molars, partially or totally unerupted, and teeth that belong to other dental groups, obviousness recommends - due to mouth anatomy and physiology, as well as pathologic reasons - extracting the third molars, due to of the several reasons described in the present study.
\end{abstract}

Keywords: Bone remodeling. Orthodontics. Extractions. Third molars. Premolars.

O osso é uma estrutura anatômica em constante remodelação, com designs diferentes, mutantes e maravilhosamente inconstantes. A cada nova e imediata demanda funcional, mudam a espessura das corticais, a densidade do trabeculado, a direção e o tamanho das trabéculas. A busca incessante do osso é para se adequar às funções induzidas pelas forças e movimentos decorrentes do modo de viver. O planejamento ortodôntico convencional ou com ancoragem transitória baseada na remodelação óssea leva em consideração os espaços que os dentes ocupam, ou podem ocupar, na formação de uma arcada dentária funcional e estética para o paciente. Se for necessário extrair algum dente e houver a opção entre os terceiros molares, parcial ou totalmente não irrompidos, e os dentes de outros grupos dentários, a obviedade recomenda — por conta da anatomia e fisiologia bucal, assim como por razões patológicas — optar pela extração dos dentes do siso, pelos várias motivos que serão descritos no presente trabalho.

Palavras-chave: Remodelação óssea. Ortodontia. Exodontias. Terceiros molares. Pré-molares.

${ }^{1}$ Full professor at the Dental School of Bauru, Universidade de São Paulo (FOB-USP) and in the Post-graduation program at the Dental School of Ribeirão Preto, Universidade de São Paulo (FORP-USP).
How to cite this article: Consolaro A. Third molars and premolars extraction in conventional orthodontics and in treatments based on maxillary bone remodeling with temporary anchorage: indications and care. Dental Press J Orthod. 2017 Jan-Feb;22(1):23-31. DOI: http://dx.doi.org/10.1590/2177-6709.22.1.023-031.oin

Submitted: January 23, 2017 - Revised and accepted: January 27, 2017

» The author reports no commercial, proprietary or financial interest in the products or companies described in this article.
Contact address: Alberto Consolaro

E-mail: consolaro@uol.com.br 
FIRST OF ALL, LIFE MAINTENANCE:

\section{LONG LIVE CALCIUM!}

Calcium is fundamental and without it our metabolism collapses and we die. It takes part in most of biochemical reactions, accelerates metabolism, for it activates intracellular enzymes, and it must be always available to cells. Calcium input control in the cells happens through mechanisms of selective permeability in the cellular membrane. There is around 10 thousand times more calcium outside the cells than inside them, in the cytosol (name of the gel that fills and composes the cytoplasm).

Calcium participates in almost all functions, together with other minerals, and needs to be stored and available to cells at all times, without time for warnings or previous mobilization. Food, including its mineral components, such as calcium, are absorbed in the gastrointestinal tract and taken to the liver, where they are partially or totally processed, so that they will be released and available, in the blood, to all cells and tissues.

Increased or reduced level of calcium in the blood may put one's life at risk. When there is excessive calcium in the blood plasma, it is deposited into the osseous tissue, more precisely in its mineralized collagen extracellular matrix. When the serum level goes down, parathyroid cells are led to secrete parathormone, which, once released to the blood, reaches bone cells and activates clastic resorption mechanisms in order to stabilize the amount of calcium available in the blood to be used by the cells! When vitamin D3, a hormone synthesized in the skin, gains circulation, it is important to induce calcium resorption in the intestine, helping the parathormone to establish the level of calcium in the blood, whenever it is reduced. Simultaneously, vitamin D3 stimulates the appearance of new clasts, also known as clastogenesis.

In high levels in the blood, calcium causes the parafollicular cells of thyroid to secrete calcitonin, which inhibits the cellular resorption process, reducing the transference of calcium from the bones to the blood. Estrogens greatly assist calcitonin with the bone resorption control.

As simple as that: the mineral component of the bone tissue, in terms of quality and structural density, is directly linked to the plasmatic level of calcium in the blood, that is, its serum level. Such level may be influenced by several factors, such as eating habits and life style; yet, in its essence, this mechanism that controls the level of calcium in the blood aims at preserving life!

\section{MEETING FUNCTIONAL DEMANDS: ADAPTIVE CAPACITY IN AN EXTREME WAY!}

By preserving life, the mechanisms that controls calcium serum level offer human kind constant bone remodeling, which allows an incomparable adaptive capacity of the musculoskeletal structure to the functional demands of our life style and the environment in which we live! Our skeleton, by analogy, is a never stopping wheel!

Bone remodeling is also known as bone turnover. Children and adolescents also have bone remodeling, as their bones adapt to the new sizes and functions that come with maturity.

The 206 bones of the human body are anatomic structures with different, mutant and wonderfully inconstant designs. Every time a new and immediate functional demand emerges, there are changes in cortical thickness, trabecular bone density, as well as in direction and size of the trabeculae. Bones' non-stopping search is for adjusting to the functions imposed by the forces and movements required by a certain life style.

All these morphological and functional characteristics of the bone tissue are modulated by mediators and phenomena that are associated to bone cells: osteocytes, osteoblasts, clasts, chondroblasts, chondrocytes and others. The functioning of each single cell inevitably passes by the messages that are codified in the genes, which represent items or information of a true user manual, showing to mediators how to act.

The shape of some parts and organs of the body is genetically determined and inherited from our parents. In some other parts, however, both shape and organization of what was inherited suffer great influence of factors that are external to the genes, resulting in characteristics - such as size, shape and number - that are different from what was originally determined for that region.

The influence of external factors over genes functioning resulted in the Epigenetics. More than half of the characteristics of a certain part of the body can be attributed to these epigenetic factors, which do not promote mutations in the genes, but only influence and modify their original functioning. If there is mutation, the nature is no longer epigenetic. 
Shape, volume and size of the bones are directly related to the functional demands, and not with inherited characteristics. There are no inherited definitive shape, volume and size, since our bones have their design determined by the functional demand.

Relapses in orthopedic, surgical and orthodontic procedures are associated to factors that are external to the inherited genes. What provides the results stability, in such conditions, is maintenance and constancy of the same functional demands over time. For this extensive maintenance of the functional demands, the parties involved must be in perfect balance. In any system, whenever forces are involved, perfect balance means that they nullify themselves - with a resultant that equals zero -, providing final stability to form, volume, size and local inter-relations. This perfect balance is called tensegrity.

All biological functions are managed by information that is registered in the DNA, called genes. Basically, all of our micro or macroscopic functions have a genetic nature, but not hereditary, what would necessarily involve characteristics transmitted from parents to children. Many of these functions respond to stimuli that are external to the inherited genes.

In summary, bone remodeling and its phenomena depend on a lot of genetic information to happen, but a bone's shape is associated to the functional demands that are applied, and not to what is determined by factors inherited from one's parents. In other words, relapses of orthopedic, surgical and orthodontic procedures are associated to external factors, such as tensegrity breach or altered functional demands, and not inherited genes. The term 'genetic memory' should not be applied in order to justify such relapses.

So far, we have justified the bone dynamism that we must consider in orthodontic, orthopedic and surgical planning. However, it is still common, in almost all areas of biological knowledge, considering bone tissue as a permanent and static structure. The aforementioned dynamism must be considered in cases of unerupted teeth involved in orthodontic, orthopedic and surgical therapeutic planning, as discussed in a previous paper. ${ }^{2}$

\section{BONE REMODELING ALLOWS US TO MANIPULATE BONE DESIGN IN FAVOR OF OUR PATIENTS}

Bone remodeling has broadened the limits of orthodontics and created new paradigms. ${ }^{1,3,6,7}$ In the three-di- mensional peripheral limits of the maxillaries offered by the periosteum, teeth are like levers, and their crowns represent true orthodontic joysticks. Well planned manipulation involving a set of teeth and their roots may promote changes in their design, including shape and, also, bone volume.

When it comes to games, joysticks can be overly simple and with limited movements. Yet, the most evolved models may broaden the types and extension of movements. By means of the teeth crowns, we can also manipulate their roots, with simple and limited movements when forces are applied to the brackets and wires in a conventional way. The use of anchorage devices - such as mini-implants, and more especially miniplates - expands and sophisticates the types and the extension of the orthodontic movements. ${ }^{1,3,6,7}$

It is possible to affirm that the conventional orthodontic movement with brackets and wires limits the dislocation to the individuality of each tooth. In conventional orthodontics, we have a tooth-by-tooth movement. When orthodontics is applied considering that bones are in constant remodeling process, the set of well-anchored teeth and roots will be moved and replaced together with the bone, as a whole. Dental movements do not occur only at the alveolus level. Bone remodeling also happens in the maxilla and mandible bones, or in a specific maxillary region to be eventually redesigned in a morphological way.

When teeth are moved one by one, in conventional orthodontics, the periodontal ligament represents the main biological tool and it uses nothing but the remodeling of the alveolar process to reach the planned goal. Such job is as thorough as the one of a watchmaker or a goldsmith, demanding more time for its conclusion. When bone remodeling is used in the whole jawbone, the redesign of the bone and the dental arches is done more quickly with time, for all the bones are being three-dimensionally replaced in a simultaneous way, in accordance with the stimulus applied to an anchorage that is capable of coping with this larger and wider dimension, such as miniplates!

In order to teach, study and understand dental movement, the typodont was once widely used. It simulates dental dislocation in wax, that represents, in a static way, the bone. We now know that bones are no longer like that. In fact, they have never been! Bones are constantly being remodeled. They are in movement and redesigning 
themselves in accordance with functional needs. With the appearance of anchorage devices, contemporary orthodontists have learned how to use it in their own favor, and on their patients' favor. Currently, a contemporary typodont requires the wax to represent an intelligent and dynamic bone. Considering that wax does not allow that, we must create this intelligent bone by making use of informatics, using mathematical models capable of reproducing the dynamism of bone remodeling.

\section{D STUDIES, BONE VOLUME AND SPACES: UNERUPTED TEETH}

In this new configuration of therapeutic planning, in which bones and teeth must be thought and planned three-dimensionally, with the most peripheral design dictated by the periosteum; volume and space for the teeth must also be considered, always in 3D.

When mechanics is applied based in an anchorage with miniplates, one must picture, since the beginning, how tooth movement, in the dynamic and in constant remodeling bone support, will take place. There is no room for applying the orthodontic treatment in steps and, then, making a decision based on the outcomes of the new situation. Planning must be complete, since the very beginning of the treatment.

In many cases, the teeth will suffer distalization, and those which are unerupted and misplaced may be an obstacle for the adequate resizing of bone volume and the dental arch, leading to its extraction (Fig 1 to 7). In other situations, unerupted teeth will

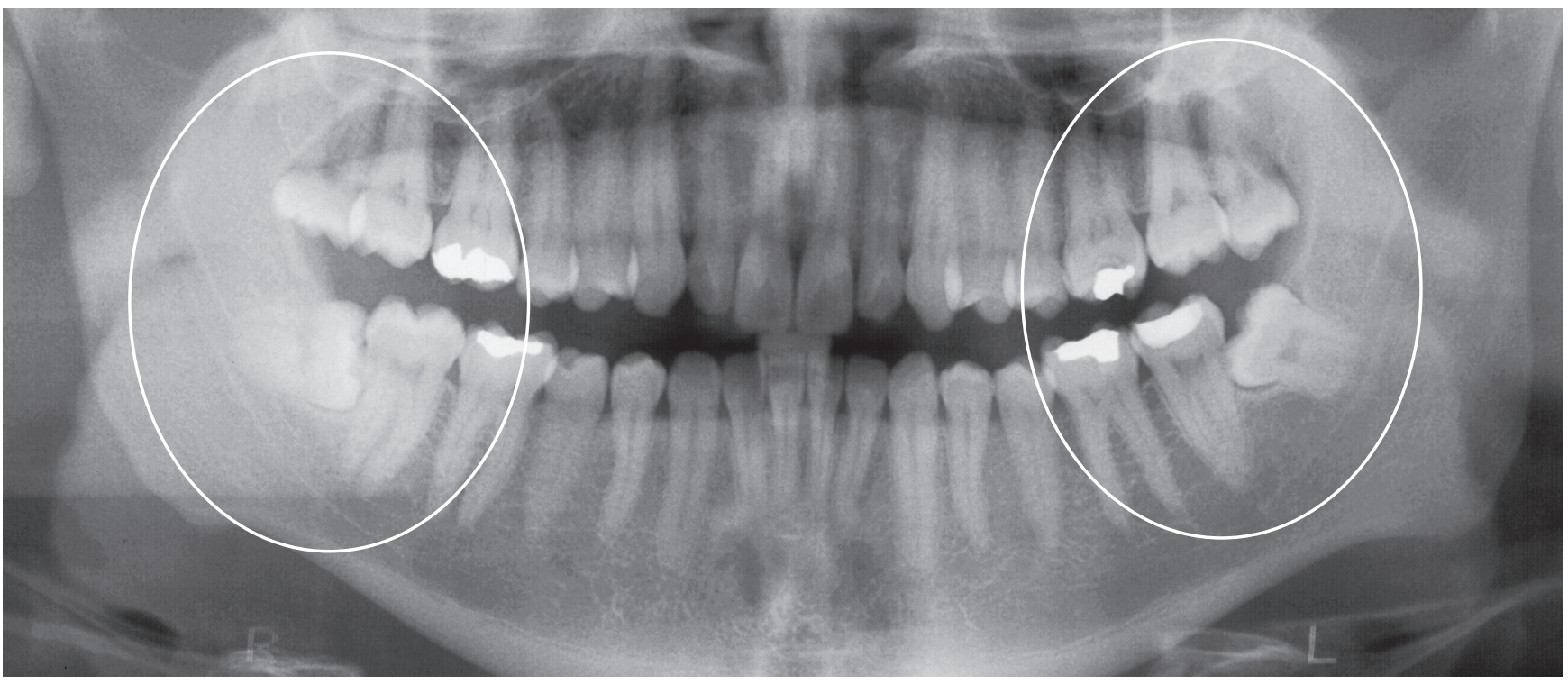

Figure 1 - Positions and relations of lower third molars partially erupted, with risk of tooth resorptions in the second molars, due to osseous growth vectors, regardless of age. It is worth highlighting that upper third molars 'occlude' over the lower ones, contributing to the setting of pericoronitis.
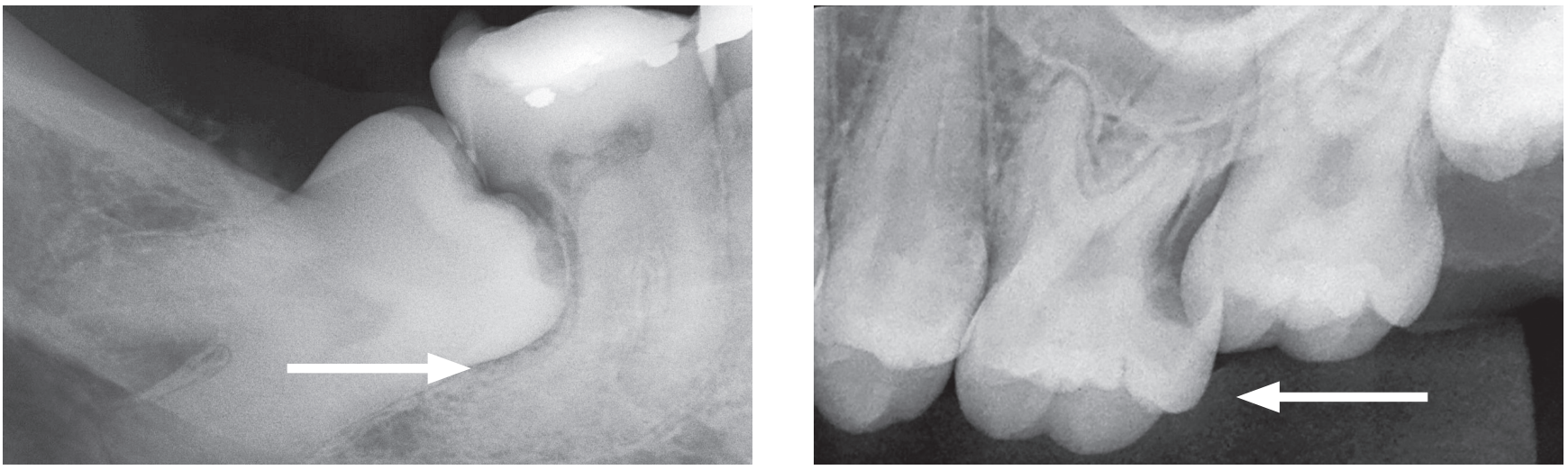

Figure 2 - Tooth resorptions associated to partially unerupted teeth 
be moved to the right place to perform an adequate function, whenever it is possible, all in accordance with the planning and the total context of the case.

It is important to emphasize that this concern is not only about cases in which additional and temporary anchorage will be used; ${ }^{4,5,8}$ in the cases of conventional orthodontics, it is also important to be concerned about partially or totally unerupted teeth, especially third molars. Long gone are the days when some professionals considered the limit of the orthodontic approach only up to the first or second molars (Figs 4, 5, 6, 7). Third molars are also a responsibility of orthodontists and their planning; there is no more room for discharging orthodontic patients with partially or totally unerupted third molars, as such conduct can be legally considered as being professional negligence.

\section{SITUATIONS THAT POINT TO THE EXTRACTION OF UNERUPTED THIRD MOLARS}

The chance of odontogenic tumors derived from unerupted teeth, more specifically of their pericoronal follicle, exists, although it is a small one. Many cases are diagnosed and described because the absolute number of people multiplied by their 32 teeth is too large; but in terms of percentage, the frequency is very low. ${ }^{5,8}$ The percentage of odontogenic tumors associated to unerupted teeth is high in published case reports, but we should consider that those are samples that were accumulated over time.

When the extraction of unerupted third molars is indicated aiming at cysts (Fig 1 to 7) and odontogenic tumors prevention, removing the pericoronal follicle together with the tooth is fundamental. ${ }^{5,8}$ Its reduced enamel epithelium and the remains of the dental lamina are the dental structures responsible for the appearance of cysts and odontogenic tumors. It is no use preventively removing, for that purpose, only the tooth and not the pericoronal follicle.

The most important statistically and day-to-day indications for partially or totally removing unerupted third molars are:

1) Chronic pericoronitis, with its intensification bursts (Fig 3 and 4).

2) Paradental cyst resulting from this repetitive cycle of chronic and acute pericoronitis (Figs 4, 5, 6, 7).
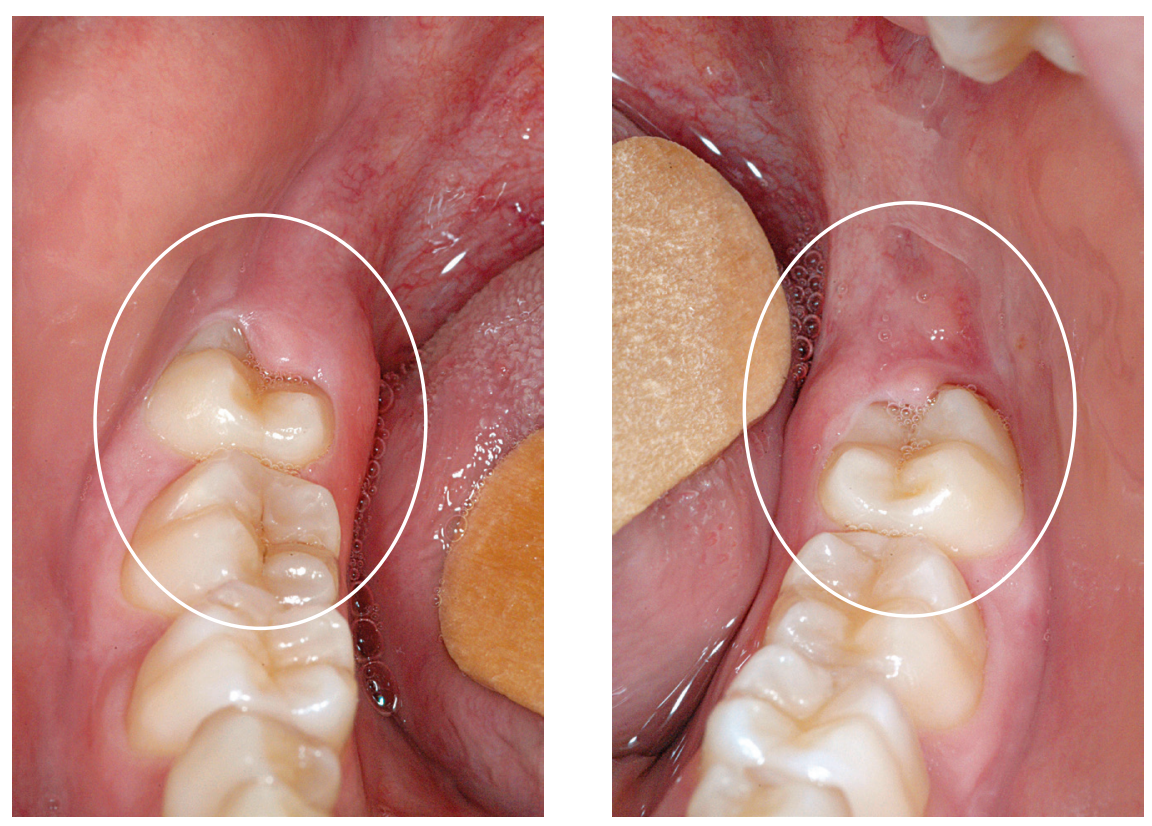

Figure 3 - Lower third molars in occlusion, but with their occlusal face partially covered by gingival operculum/pericoronal sack or, yet, with their coronary distal face in contact with the pericoronal or periodontal tissues. In such clinical conditions, they must be considered to be partially erupted teeth, and it is necessary to prevent from eventual consequences. 
3) Tooth resorption of the second molar, which, due to its proximity, tends to increase during the terminal growth of the maxillaries, whose vectors try to mesially move it (Fig 1,2).

The pericoronal follicle of a partially or totally unerupted tooth and near the periodontal ligament (of the second molar, for instance) compresses the vessels and cause the cementoblasts to die, exposing the mineralized part of the roots, what attracts the clasts to that area (Fig 2). These cells are sharply stimulated by the mediators that function as inductors of resorption phenomena, which are present in the pericoronal follicles - especially the EGF, or epithelial growth factor - , to reabsorb mineralized tissues.

Orthodontically, discharging a patient with partially or totally unerupted teeth involves considerably increasing the chances of their consequences (Figs 6 and 7). Indeed, such consequences may occur before, during or after the orthodontic treatment. Every dentistry professional, including orthodontists, must raise awareness of their patients, and of those who are responsible for them, about the consequences, as well as planning and indicat- ing the extraction of partially or totally unerupted teeth, in the context of a complete orthodontic planning.

\section{EXTRACTION OF OTHER TEETH IN THE ORTHODONTIC PLANNING, IN COMPARISON WITH THIRD MOLARS EXTRACTION}

Partially or totally unerupted third molars normally have a deformed anatomy considering molars standard, especially for the roots. Not always will there be adequate space for reaching the occlusal plane and, at the same time, presenting healthy gingival tissues which allow appropriate cleaning, with emphasis being placed on the distal face of their crowns and roots. Persistence of an entire distal coronary face in contact with soft and hard tissues allows us to classify the tooth situated that way as partially erupted, causing the same consequences as of when it is not in the occlusal plane. Inserting the third molars into the dental arch involves giving them a healthy distal region in all senses.

During the conventional orthodontic planning or with temporary anchorage based on bone remodeling, it is taken into consideration the spaces occupied by the teeth in the formation of a functional and esthetic
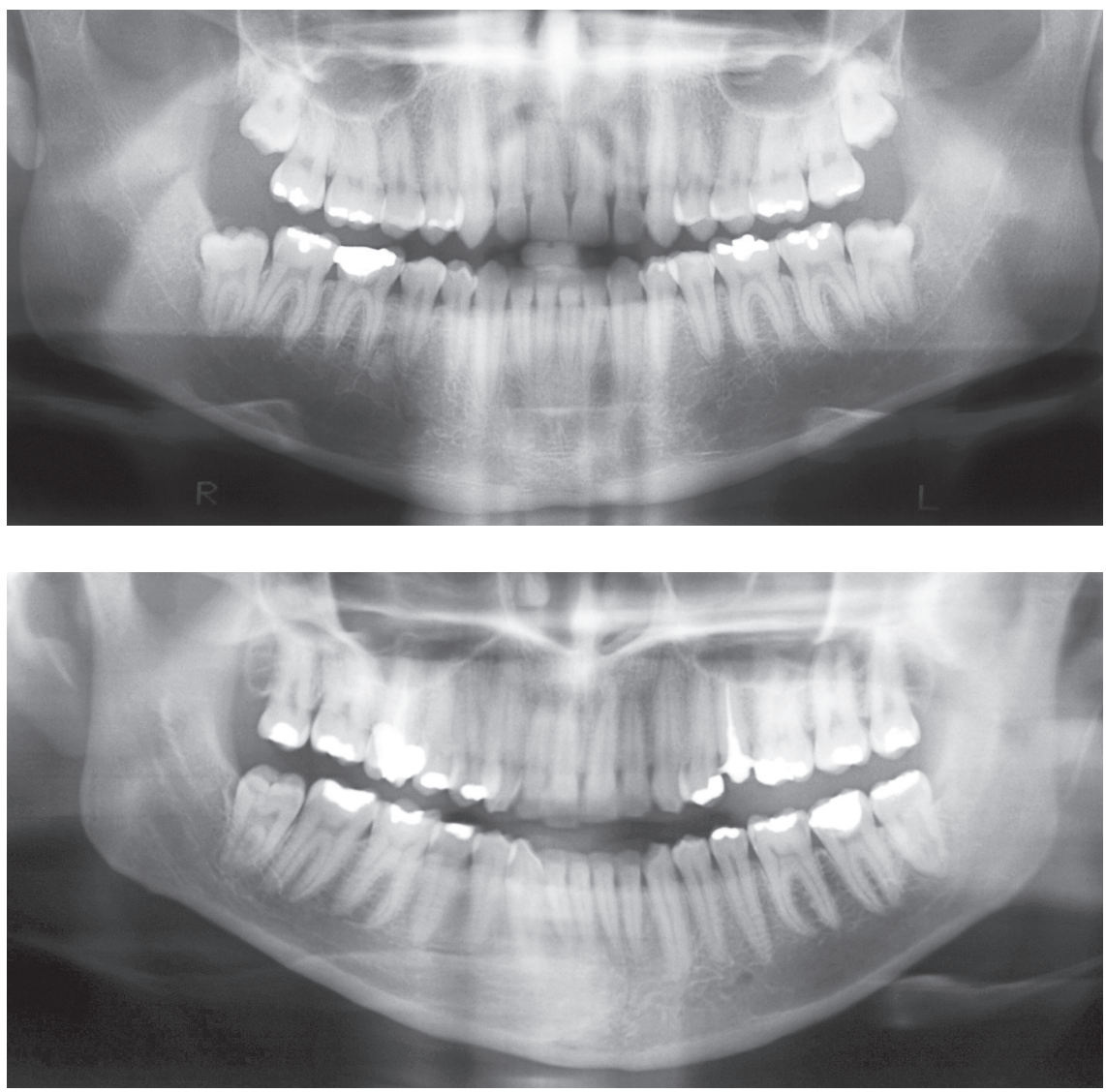

Figure 4 - Partially erupted third molars still subject to the possible consequences of their permanence, also by the occlusion of the upper teeth over third molars, still with pericoronal tissues in their crowns. 

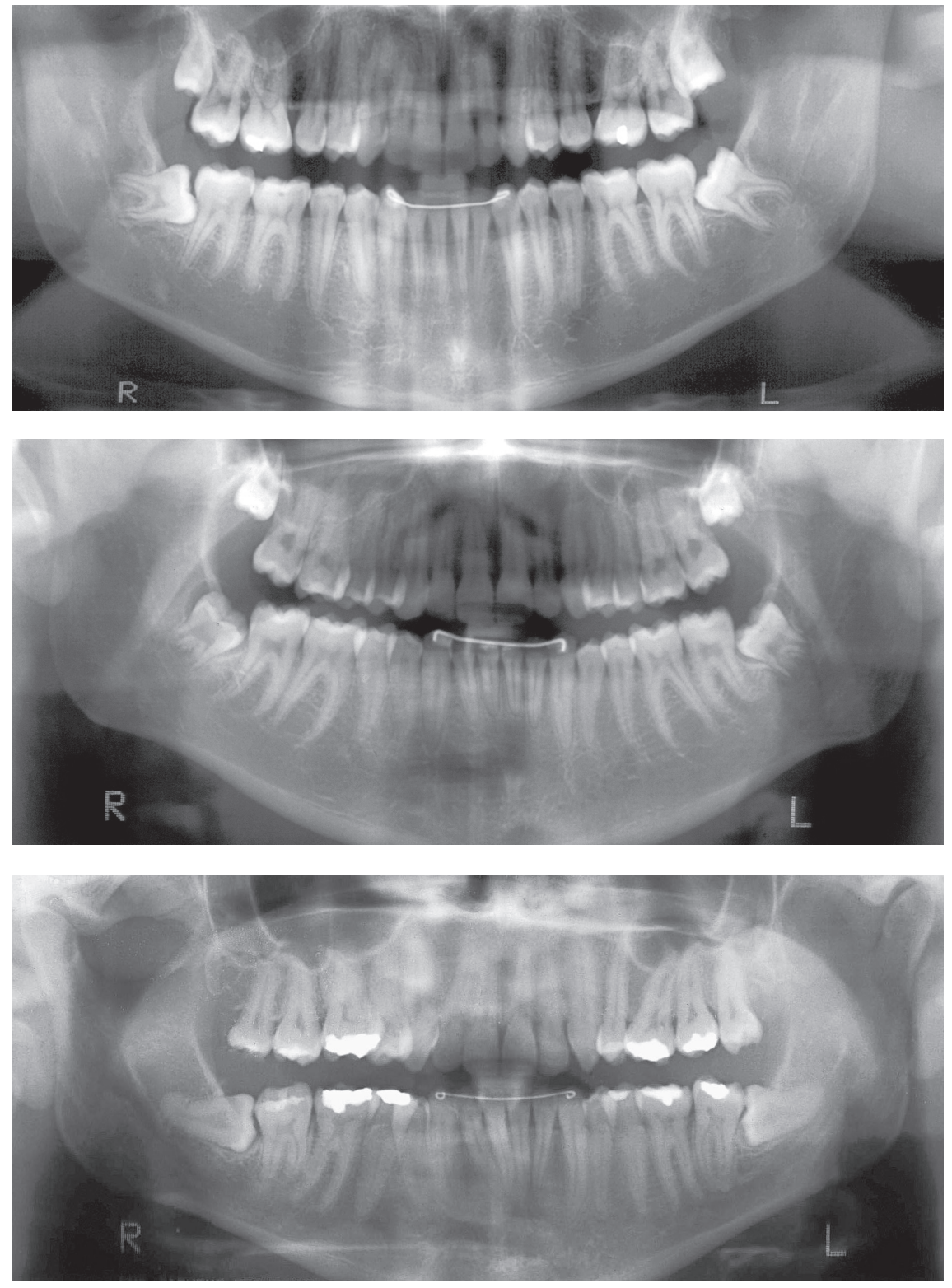

Figure 5 - Partially erupted third molars in orthodontically finalized patients. In general, before finalizations, patients should provide the surgical removal of these teeth, in order to prevent from their possible consequences. dental arch for the patient. If it is necessary to extract a tooth and the professional may choose between partially or totally unerupted third molars and teeth from other dental groups, obviousness, due to mouth anatomy and physiology, recommends choosing to extract the wisdom teeth, because of the several reasons described in the present study.

The planning to obtain spaces for a complete esthetic and functional dental arch may be reached with teeth extraction, as it happens, with certain frequency, to premolars. Yet, in those cases of partially or totally unerupted third molars, the indication is associated to obstacles and undesirable positions that they represent to bone remodeling of the maxillaries, and the prevention of the most commonly reported consequences in teeth in that situation, during or after orthodontic treatment.

In treatment planning, comparing premolars with third molars extractions does not seem to be orthodontically applicable. In order to close the spaces left by the extraction of premolars, conventional orthodontics is required, with great movements, tooth by tooth, what 

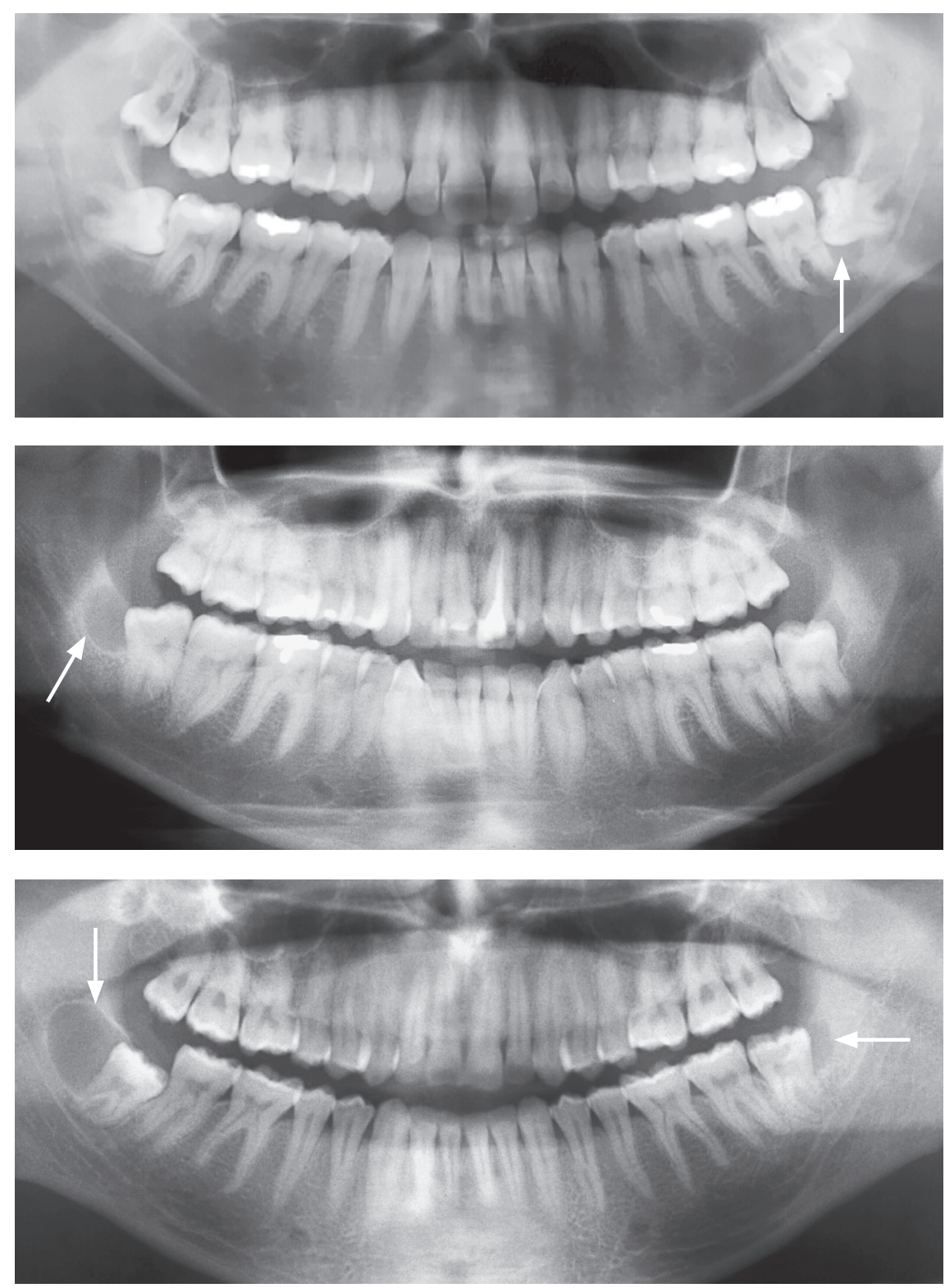

Figure 6 - Paradental cysts (arrows) in partially erupted third molars. increases the risk of tooth resorptions. However, it must be observed that indicating the extraction of premolars is part of normal orthodontic context. As for third molars, extractions have other indications, already mentioned, which override the creation of spaces for other teeth in the dental arch, except for some very specific and special situations. One of them has to do with modifications of the maxillary morphology, through bone remodeling associated to temporary anchorage, in which partially or totally unerupted teeth are an anatomic obstacle to the passage or movement of other teeth.

\section{FINAL CONSIDERATION}

Bones are anatomic structures in constant remodeling, with different, mutant and wonderfully inconstant designs. Every time a new functional demand emerges, there are changes in cortical thickness, trabecular bone density and direction and size of the trabeculae. Bones' non-stopping search is for adjustment to the functions that are induced by the forces and movements required by a certain life style.

In conventional orthodontic planning or with temporary anchorage based on bone remodeling, one must take 


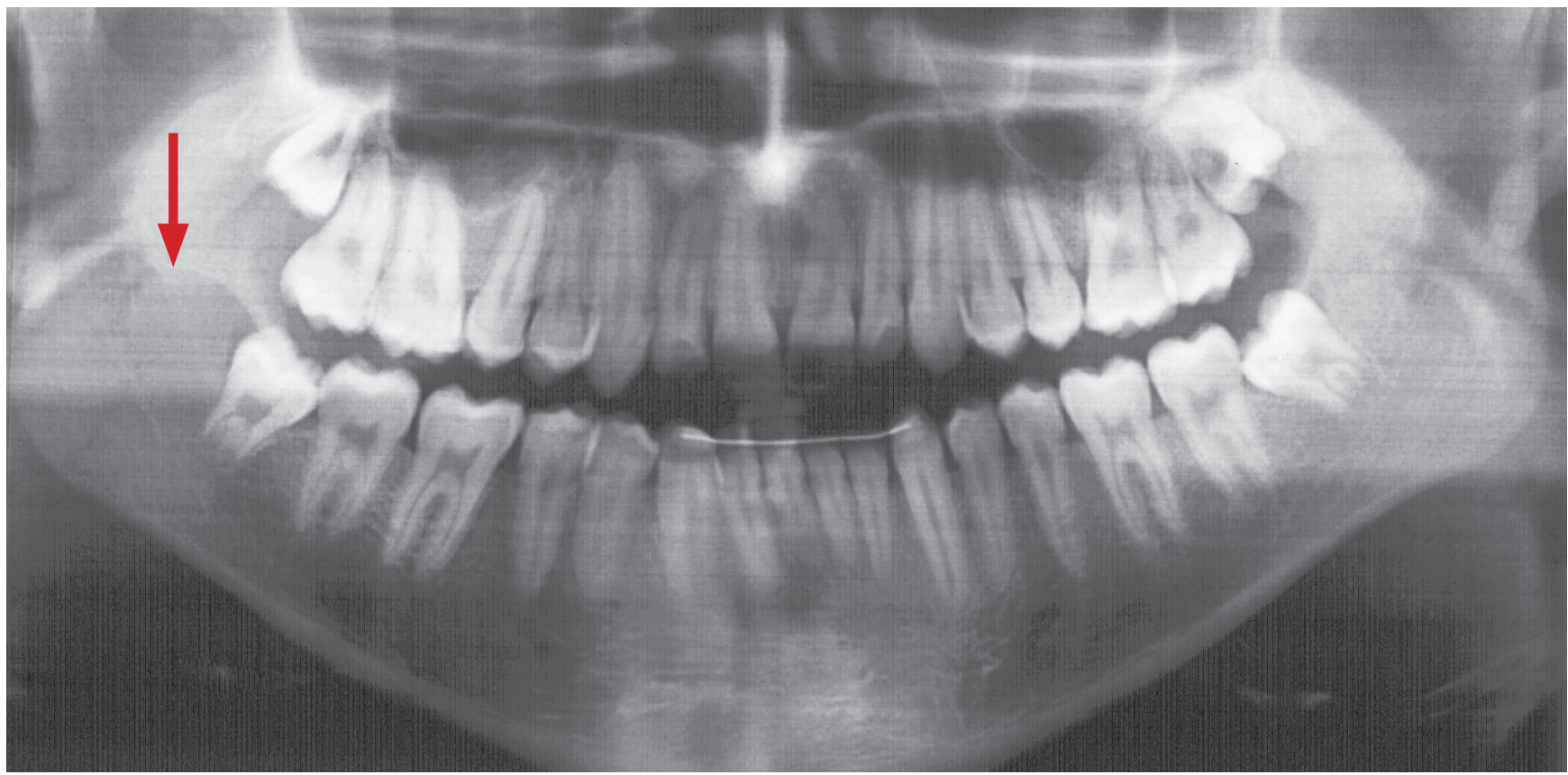

Figure 7 - Paradental cyst (arrow) in a partially erupted third molar of a patient who previously underwent orthodontic treatment.

into account the spaces that are - or may be - occupied by the teeth, in the dental arch formation, through the functional and esthetic points of view for the patient. In case it is necessary to extract a tooth, and if there is the possibility of choosing between partially and totally unerupted third molars and teeth that belong to other groups, obviousness (due to mouth anatomy and physiology) recommends extracting the wisdom teeth, for the several reasons previously described in this paper.

The extraction of teeth from other dental groups, more commonly premolars, always represents an alternative for orthodontic planning, as long as they can be justified in the esthetic and functional facial context of the patient. Regarding third molars, extractions have other indications, which have already been mentioned, and override the indication for creating spaces for other teeth in the dental arch, except for some very specific and especial situations.
REFERENCES

1. Consolaro A. Remodelação óssea no preparo para cirurgia ortognática: a compreensão otimiza o resultado final. Rev Clín Ortod Dental Press. 2016 Abr-Maio:15(2):100-8.

2. Consolaro A. Exodontia de terceiros molares e pré-molares na Ortodontia convencional e na baseada em remodelação óssea maxilar com ancoragem transitória. Rev. Clin. Ortod. Dental Press. 2016 Dez-2017 Jan:15(6):133-6

3. Consolaro A. Miniplates and mini-implants: bone remodeling as their biological foundation. Dental Press J Orthod. 2015 Nov-Dec; 20(6):16-31

4. Consolaro A. Planejamento ortodôntico e cirurgia de dentes não irrompidos: quando, quantos e quais suas conseqüências. Rev Clín Ortod Dental Press. 2006:5(2):107-11

5. Consolaro A. Caracterização microscópica de folículos pericoronários de dentes não irrompidos e parcialmente irrompidos. Sua relação com a idade [tese]. Bauru (SP): Universidade de São Paulo; 1987.

6. Consolaro A, Consolaro RB. Bone remodeling and mouth rehabilitators plans with mini-implants and mini-plates: some analogies to facilitate understanding. Dental Press Implantol. 2015 July-Sept;9(3):15-37.

7. Crockett JC, Rogers MJ, Coxon FP, Hocking LJ, Helfrich MH. Bone remodelling at a glance. J Cell Sci. 2011 Apr 1;124(Pt 7):991-8.

8. Damante $\mathrm{JH}$. Estudo dos folículos pericoronários de dentes não irrompidos e parcialmente irrompidos. Inter-relação clínica, radiográfica e microscópica [tese]. Bauru (SP): Universidade de São Paulo; 1987. 